\title{
POLA PEMBINAAN AGAMA PADA ANAK DALAM KELUARGA BURUH PABRIK DI DESA LABRUK LOR LUMAJANG
}

\author{
Yudi Ardian Rahman \\ Sekolah Tinggi Agama Islam Al-Islah Bondowoso, Indonesia \\ E-mail: ardianyudi439@gmail.com \\ Siti Ati'ul Mas'ullah \\ Institut Agama Islam Syarifuddin Lumajang, Indonesia \\ E-mail: siti_atiul@yahoo.com
}

\begin{abstract}
Abstrak: Tulisan ini ingin melihat sejauh mana pola pembinaan agama dalam keluarga buruh pabrik, daya dukung dan hambatan pembinaan agama dan dampak serta manfaat bagi anak dari pembinaan agama dalam keluarga buruh pabrik di Desa Labruk Lor Lumajang. Sebagaimana diketahui, keluarga merupakan proses hubungan manusia yang paling awal terjadi, sebelum mengenal lingkungan yang lebih luas. Sebagai lembaga pembentukan pribadi, mental dan karakter, peran dan tanggung jawab orang tua merupakan faktor yang utama. Selain itu, orang tua juga dijadikan acuan atau contoh oleh anaknya. Penelitian ini termasuk jenis penelitian kualitatif lapangan. Dalam penelitian ini, penulis menggunakan metode penelitian field research yaitu penelitian dengan melakukan pengamatan langsung terhadap objek penelitian guna memperoleh informasi terhadap masalah-masalah yang dibahas. Penelitian dilakukan di bulan April-Mei 2018. Hasil penelitian ini menunjukkan bahwa pola pembinaan agama pada anak dalam keluarga buruh pabrik di desa Labruk Lor yakni menggunakan pola pembinaan anak secara permisif, otoriter dan demokratis. Hal tersebut disebabkan karena faktor ekonomi, lingkungan, pendidikan orang tua, keturunan dan budaya. Implikasi dari hasil penemuan ini menunjukkan bahwa terdapat hal positif yang bisa diambil hikmah, yakni anak akan lebih bertanggung jawab, lebih disiplin, kreatif, mandiri dan mampu mengotrol emosi.
\end{abstract}

Kata Kunci: Pola Pembinaan Agama Pada Anak, Keluarga Buruh Pabrik

\section{Pendahuluan}

Keluarga merupakan proses hubungan manusia yang paling awal terjadi, sebelum mengenal lingkungan yang lebih luas. Sebagai lembaga pembentukan pribadi, mental dan karakter, keluarga juga harus mampu merangkap kepentingan masing-masing anggotanya. Dalam hal ini, peran dan tanggung jawab orang tua merupakan faktor yang utama, mereka merupakan pimpinan sekaligus pengambil keputusan. Selain itu orang tua juga dijadikan acuan atau contoh oleh anaknya, baik kebiasaan, sifat, cara bicara maupun cara bertindak. Hal ini akan lebih besar 
pengaruhnya karena pada umumnya seorang anak lebih banyak menghabiskan waktunya tinggal bersama keluarga, saat si anak masih kecil.

Manusia sebagai kholifah Allah di bumi mempunyai keutamaan di banding dengan makhluq yang lain. Banyak hal positif yang terdapat dalam diri manusia, namun di antara sekian keistimewaan positif tersebut manusia tetap mempunyai kelemahan yang bersifat negatif, seperti yang disampaikan Allah dalam al-Qur'an bahwa manusia adalah amat dhalim dan amat bodoh. ${ }^{1}$ Bahkan di ayat lain Allah menyatakan bahwa manusia adalah makhluq yang banyak membantah dan menentang ajaran Allah yang telah menciptakannya. ${ }^{2}$ Artinya peran agama dalam hidup dan kehidupan manusia memiliki peran yang sangat penting, karena pada dasarnya manusia memiliki kecenderungan naliriah yang bersifat esensial dalam jiwanya, berupa keinginan untuk mencari sesuatu yang berada diluar dirinya, idealnya yang bisa dijadikan sandaran hati untuk mencari makna dari hidup. Oleh sebab itu pembinaan agama pada anak sangat diperlukan.

Anak mempunyai hak terhadap orang tuanya, yaitu orang tua berkewajiban memelihara dan mendidik. Pemeliharaan anak artinya tanggung jawab orang tua untuk mengawasi, memberi pelayanan yang semestinya serta mencukupi kebutuhan hidup dari seorang anak oleh orang tuanya. Selanjutnya, tanggung jawab pemeliharaan berupa pengawasan dan pelayanan serta mencukupi nafkah anak tersebut bersifat kontinyu sampai anak tersebut mencapai batas umur yang legal sebagai orang dewasa yang telah mampu berdiri sendiri. Dan pendidikan anak artinya kewajiban orang tua untuk memberikan pendidikan dan pengajaran yang memungkinkan anak tersebut menjadi manusia yang mempunyai kemampuan dan kecakapan sesuai dengan pembawaan bakat anak tersebut yang akan dikembangkan di tengah-tengah masyarakat sebagai landasan hidup dan penghidupannya setelah ia lepas dari tanggung jawab orang tua.

Upaya membesarkan, mendidik anak merupakan bagian yang tidak terpisahkan dari rangkaian kewajiban yang harus dilaksanakan oleh orang tua.Kewajiban ini harus dilaksanakan secara selaras dan seimbang agar terjadi

${ }^{1}$ QS: al-Ahzab, 72

2 QS: al-Kahfi, 54 
keseimbangan dalam pertumbuhan dan perkembangan anak. Namun, dalam kenyataanya tidak semua keluarga dalam hal ini orang tua dapat melaksanakan perannya dengan baik, karena latar belakang beberapa faktor salah satu faktornya adalah pekerjaan. Orang tua lebih sering berada di luar rumah karena kesibukannya bekerja, sehingga kasih sayang serta perhatian kepada anknya berkurang. Kurangnya komunikasi antara anak dengan orang tua juga dapat berpengaruh dalam membentuk kepribadian anak.

Di desa Labuk Lor Luamjang khususnya di Dusun Laban RW 1 sampai 3 Kecamatan Lumajang Kabupaten Lumajang 60 \% masyarakat didalamnya berprofesi atau bekerja sebagai buruh pabrik. Kondisi perekonomian yang kurang mencukupi menuntut mereka bekerja siang dan malam demi memnuhi kebutuhan hidup mereka sehingga membiuat waktu bekumpul bersama keluarga terutama anak berkurang atau bahkan tidak ada. Bila dilihat dari waktu bekerjanya, sebagian waktunya dihabiskan di pabrik. Normalnya Jika sift pagi mereka berangkat mulai jam 07.00 WIB dan pulang jam 15.00 WIB, sedangkan jika sift malam mereka berangkat mulai jam 15.00 WIB sampai jam 23.00 WIB. Jika terkena long shiff berangkat jam 07.00 WIB pulang jam 19.00 WIB. Kebijakan ini berbeda-beda setiap pabrik dan tergantung dari bagian pekerjaan mereka di pabrik.

Dilihat dari fenomena di atas, memungkinkan keluarga atau orang tua yang bekerja di pabrik kurang mengawasi atau memberikan perhatian mereka terhadap anaknya terutama dalam pendidikan agama.

\section{Metode Penelitian}

Pendekatan yang dilakukan dalam penelitian ini adalah penelitian lapangan (field research), yakni kegiatan penelitian yang obyeknya langsung, yang didapat melalui wawacara langsung dengan keluarga yang melakukan perkawinan beda agama. ${ }^{3}$ Sedangkan Jenis penelitian ini adalah deskriptif analitis, yakni suatu penelitian yang meliputi proses pengumpulan data, penyusunan dan penjelasan data. Data yang terkumpul kemudian dianalisis dan diinterpretasi ${ }^{4}$.

3 Winarno Surakhmad, Pengantar Penelitian Ilmiah 9 Dasar Metode Teknik (Bandung: Tarsito, 1990), 191.

${ }^{4}$ Ronny Kountur, Metode Penelitian Untuk Penulisan Skripsi dan Tesis, cet. ke-1 (Jakarta: PPM, 2003), 53. 
Lokasi penelitian adalah Desa Labruk Lor Lumajang. Desa Labruk Lor merupakan salah satu desa di Wilayah Kecamatan Lumajang. Secara geografis Desa Labruk Lor adalah salah satu desa dari 12 desa di Wilayah Kecamatan Lumajang. Secara geografis Desa Labruk Lor Kecamatan Lumajang dengan batas-batas : 1) Sebelah utara berbatasan dengan Kelurahan Citrodiwangsan Kecamata Luamajang, 2) Sebelah selatan berbatasan dengan Desa Labruk Kidul Kecamatan Lumajang, 3) Sebelah barat berbatasan dengan Desa Petahunan Kecamatan Lumajang, 4)Sebelah timur berbatasan dengan Desa Grati Kecamatan Lumajang. ${ }^{5}$

Desa Labruk Lor Kecamatan Lumajang terbagi menjadi 4 (empat) Dusun, 5 RW dan 17 RT Yaitu : 1 1) Dusun I dengan nama lain Dusun Krajan, terdiri dari 1 RW yaitu RW 01, dan dibantu oleh 04 RT, 2) Dusun II dengan nama lain Dusun Laban, terdiri dari 1 RW yaitu RW 02, dan dibantu oleh 03 RT, 3) Dusun III dengan nama lain Dusun Panjang Sari, terdiri dari 1 RW yaitu RW 03 dengan dibantu oleh 03 RT, 4)Dusun IV dengan nama lain Dusun Jurang Mangu, terdiri dari 2 RW yaitu RW 4,RW 5 dengan dibantu oleh 4 RT.

\section{Pengertian Pola Pembinaan Agama Anak}

Menurut Kamus Besar Bahasa Indonesia, pola berarti gambar, contoh dan model. ${ }^{7}$ Adapun pembinaan berarti usaha, tindakan dan kegiatan yang diadakan secara berdaya guna dan berhasil guna untuk memperoleh hasil yang lebih baik. ${ }^{8}$

Pembinaan adalah usaha sadar yang dilakukan dengan sabar, berencana, teratur dan terarah untuk meningkan pengetahuan, sikap, keterampilan, subjek didik dengan tindakan-tindakaan pengarahan, bimbingan dan pengawasan untuk mencapai tujuan. ${ }^{9}$

Dari definisi tersebut dapat disimpulkan bahwa pola pembinaan agama adalah usaha atau cara untuk memberikan gambaran kepada anak atas kegiatan yang sudah ada dan dilakukan agar menuju yang lebih baik melalui bimbingan dan memberikan pengetahuan dan kecakapan yang baru. Pembinaan memberikan arah penting dalam

\footnotetext{
5 Sumber dari profil desa Labruk Lor tahun 2016. Diakses pada 18 April 2018.

${ }^{6}$ Sumber dari profil Desa Labruk Lor tahun 2016. Diakses pada 18 April 2018.

${ }^{7}$ Hasan Alwi, Kamus Umum Bahasa Indonesia (Jakarta: BalaiPustaka, 2005), 109.

${ }^{8}$ Departemen Pendidikan dan Kebudayaan, Kamus Besar Bahasa Indonesia (Jakarta: Balai Pustaka, 1990), 37.

${ }_{9}$ S.Hidayat, Pembinaan Generasi Muda (Surabaya: Study Group, 1987), 26.
} 
masa perkembangan anak, khususnya dalam perkembangan spiritual. Untuk itu pembinaan bagi anak dalam lingkungan keluarga yang memilki waktu berkumpul dengan keluarga sangat iperlukan guna memberikan arah dan penentuan pandangan hidupnya mengingat keluraga merupakan tempat belajar anak pertama kali.

\section{Masa Anak-Anak/ Masa Sekolah (Usia 6-12 Tahun)}

Masa usia sekolah adalah masa matang untuk belajar atau masa untuk sekolah. Disebut masa matang untuk belajar karena mereka sudah berusaha mencapai sesuatu, sedangkan masa matang untuk bersekolah, karena mereka sudah menginginkan kecakapan-kecakapan baru, yang dapat diberikan oleh sekolah. ${ }^{10}$

Mulai anak umur 6 tahun, anak sudah matang untuk masuk sekolah. Masa anak sekolah adalah usia 6-12 tahun, pada masa ini anak memasuki masa belajar di dalam dan di luar sekolah. Banyak aspek perilaku dibentuk melalui penguatan (reinforcement) verbal, keteladanan dan identifikasi. ${ }^{11}$

\section{Macam-macam Pola Pembinaan Agama Anak}

Untuk mewujudkan kepribadian anak, menjadi manusia dewasa yang memiliki sikap positif terhadap agama, sehingga perkembangan keagamaannya baik, kepribadian kuat dan mandiri, berperilaku ihsan, potensi jasmani dan rohani serta intelektual yang berkembang secara optimal, maka ada berbagai cara dalam pola asuh yang dilakukan oleh orang tua yaitu:

Macam-macam pola pembinaan / asuh orang tua terhadapanak dapat dikelompokkan sebagai berikut :

1. Pola Pembinaan Permisif

Pola pembinaan Permisif adalah jenis pola mengasuh anak yang acuh tak acuh terhadap anak, jadi apapun yang mau dilakukan anak diperbolehkan seperti tidak sekolah, bandel, melakukan banyak kegiatan maksiat, pergaulan bebas, dan sebagainya. Biasanya pola asuh yang seperti ini diakibatkan oleh orang tua yang

\footnotetext{
${ }^{10}$ Conny, Semiawan, dkk. Pengenalandan Pengembangan Bakat Sejak Dini (Bandung: PT.Remaja R0sda Karya, 2008), 29.

11 Abu Ahmadi, Munawar Sholeh, Psikologi Perkembangan (Jakarta: PT. Rineka Cipta, 2005), 70. 
terlalu sibuk dengan pekerjaan, atau kesibujkan lainnya yang akhirnya lupa untuk mendidik anak dan mengasuh anak degan baik. ${ }^{12}$

Definisi pola asuh atau pembinaan anak menurut para ahli berbeda-beda. Menurut Hurlock, orang tua yang menerapkan pola asuh permissif memperlihatkan ciri-ciri orang tua yang cenderung memberikan kebebasan penuh pada anak tanpa ada batasan dan aturan dari orang tua, tidak adanya hadiah atau pun pujian meski anak berperilaku sosial baik, tidak adanya hukuman meski anak melanggar peraturan. ${ }^{13}$

Gunarsa, mengemukakan bahwa orang tua yang menerapkan pola asuh permissif memberikan kekuasaan penuh pada anak, tanpa dituntut kewajiban dan tanggungjawab, kurang kontrol terhadap perilaku anak dan hanya berperan sebagai pemberi fasilitas, serta kurang berkomunikasi dengan anak. Dalam pola asuh ini, perkembangan kepribadian anak menjadi tidak terarah, dan mudah mengalami kesulitan jika harus menghadapi larangan-larangan yang ada di lingkungannya. ${ }^{14}$

Dalam pola asuh permisif terdapat beberapa aspek yang terkandung di dalamnya. Secara garis besar pola asuh orang tua terdiri dari empat aspek, antara lain kontrol, hukuman dan hadiah, dominasi, komunikasi. ${ }^{15}$ Empat aspek tersebut terdapat dalam semua jenis pola asuh, termasuk dalam pola asuh permisif hanya saja kadarnya yang berbeda.

Proboningrum menjelaskan bahwa aspek-aspek dari salah satu jenis pola asuh, yaitu pola asuh permisif orang tua, antara lain, pertama, orang tua bersifat toleran terhadap anak, orang tua tidak peduli dengan tindakan anak yaitu dengan tidak ada batasan atau peraturan-peraturan tertentu dalam keluarga. Kedua, hukuman atau hadiah tidak pernah diberikan, tidak ada tindakan dari orang tua terhadap sikap anak baik yang bersifat positif maupun negatif, yang berupa hadiah atau hukuman. Ketiga, komunikasi hampir tidak ada, orang tua dan anak jarang sekali terjalin komunikasi yang melibatkan kedua belah pihak yang aktif.

12 Syamsul Kurniawan, Pendidikan Karakter (Yogyakarta : Ar-Ruzz Media, 2016), 80.

${ }^{13}$ Hurlock, Elisabeth, Psikologi Perkembangan Edisi Kelima (Jakarta: Erlangga, 2006)

14 Pengantar Psikologi Edisi Kesebelas (Batam: Interaksara Gunarsa, Singgih, 2000)

15 Mussen, P. H, Pengembangan dan Kepribadian Anak (Jakarta: Arcan, 1989),399. 
Semua keputusan diserahkan kepada anak, kebebasan diberikan kepada anak sepenuhnya dalam pengambilan keputusan tanpa memperhatikan kebutuhannya. Keempat, kontrol terhadap anak longgar, tindakan orang tua yang tidak peduli dengan semua tindakan anak atau sikap anak. ${ }^{16}$

2. Pola Pembinaan Otoriter

Pola pembinaan otoriter adalah pola pengasuhan anak yang bersifat memaksa, keras dan kaku di mana orang tua akan membuat berbagai macam aturan yang harus dipatuhi oleh anak tanpa mau tau perasaan sang anak. Orang tua akan marah jika anak-anaknya melanggar peraturan yang sudah dibuat dan seringkali memberikan hukuman mental dan fisik kepada anak alasannya agar anak terus tetap patuh dan disiplin.

Definisi pola asuh otoriter menurut beberapa ahli juga berbeda-beda. Hurlock mengemukakan bahwa orang tua yang mendidik anak dengan menggunakan pola asuh otoriter memperlihatkan ciri - ciri sebagai berikut: orang tua menerapkan peraturan yang ketat, tidak adanya kesempatan untuk mengemukakan pendapat, anak harus mematuhi segala peraturan yang dibuat oleh orang tua, berorientasi pada hukuman (fisik maupun verbal), dan orang tua jarang memberikan hadiah ataupun pujian.

Pola pembinaan Demokratis adalah pola asuh yang dimana memberikan kebebasan anak untuk berkreasi dan mengeksporasi berbagai hal sesuai dengan kemampuan annak dengan batasan dan pengawasan yang baik dari orang tua. ${ }^{17}$ Adapun indikator-indikator pola asuh demokratis diantaranya adalah sebagai berikut:

a. Kedisplinan, dalam kehidupan sehari-hari, disiplin sering dikaitkan dengan hukuman, dalam arti disiplin diperlukan untuk menghindari terjadinya hukuman karena adanya pelanggaran terhadap suatu peraturan tertentu. Dalam pengertian yang lebih luas, disiplin mengandung arti sebagai suatu

16 Proboningrum, C. S. PsikologiPerkembangan (Yogyakarta: Gadjah Mada University Press, 1993), 23.

${ }^{17}$ SyamsulKurniawan, Pendidikan Karakter (Yogyakarta: Ar-Ruzz Media, 2016), 80. 
sikap menghormati, menghargai, dan mentaati segala peraturan dan ketentuan yang berlaku. ${ }^{18}$

Disiplin adalah suatu kondisi yang tercipta dan terbentuk melalui proses dari serangkaian perilaku yang menunjukkan nilai-nilai ketaatan, kepatuhan, kesetiaan, keteraturan dan ketertiban. ${ }^{19}$ Disiplin akan membuat seseorang tahu dan dapat membedakan hal-hal apa yang seharusnya dilakukan, yang wajib dilakukan, yang boleh dilakukan, yang tak sepatutnya dilakukan (karena merupakan hal-hal yang dilarang).

Kata disiplin dalam Kamus Besar Bahasa Indonesia diartikan latihan batin dan watak dengan maksud supaya segala perbuatannya selalu mentaati tata tertib (di sekolah atau kemiliteran), dan dapat pula berarti ketaatan pada aturan dan tata tertib. ${ }^{20}$ Keinginan untuk menegakkan disiplin adalah sejalan dengan fitrah manusia. ${ }^{21}$

Kebersamaan, Kebersamaan di sini maksudnya adalah kerjasama. Kerjasama merupakan kebutuhan yang sangat penting artinya bagi kelangsungan hidup. Tanpa kerjasama tidak akan ada individu, keluarga, organisasi atau masyarakat. Tanpa kerjasama dan tanpa rasa kebersamaan keseimbangan hidup akan terancam punah.Dengan memiliki keahlian bekerjasama kita akan mudah mengungkapkan apa yang kita inginkan tanpa menyinggung orang lain.

Kegotong-royongan, Islam mengajarkan kita untuk hidup dalam kegotong-royongan. Apabila sejak dini anak sudah ditanamkan sikap yang demikian itu, maka kelak akan terlatih dan bersikap hidup dalam penuh kegotong-royongan. Beban yang berat bisa terasa ringan jika dilakukan dengan gotong-royong, dan pada akhirnya kita tidak merasa berat dalam menjalani hidup ini. Demikianlah yang menjadi salah satu tugas orang tua, agar menanamkan sikap ini sebaik-baiknya kepada anak.

\footnotetext{
${ }_{18}$ Mohamd Surya, Bina Keluarga (Semarang: CV. Aneka Ilmu, 2003), 131.

19 D. Soemarno, Pedoman Pelaksanaan Disiplin Nasional dan Teta Tertib Sekolah (Jakarta: CV. Mini Jaya Abadi, 1998), 20.

20 W.J.S. Poerwadarminta, Kamus Umum Bahasa Indonesia, (Jakarta: BalaiPustaka, 1986), cet. 12, hal. 254.

${ }^{21}$ AbuddinNata, Tafsir Ayat-ayatPendidikan (Tafsir al-Ayat al-Tarbany), (Jakarta: PT. Raja GrafindoPersada, 2002), 248.
} 
Orang tua, karena ia dipandang sebagai teladan, maka ia harus selalu membiasakan berkata benar dalam setiap perkataannya baik terhadap anggota keluarganya atau siapapun dari anggota masyarakat lainnya. Dengan demikian Menurut Khairiyah sebagaimana dikutip oleh Ahmad Tafsir, orang tua harus menjadi gambaran hidup yang mencerminkan hakikat perilaku yang diserukannya dan membiasakan anaknya agar berpegang teguh pada akhlakakhlak mulia. ${ }^{22}$

\section{Daya Dukung dan Hambat Pembinaan Agama dalam Keluarga Buruh Pabrik}

Disetiap kegiatan pasti mempunyai daya dukung dan daya penghambat dalam suatu kegiatan, berikut daya dukung dan penghambat dalam pembinaan agama anak dalam keluarga.

1. Latar Belakang Pendidikan Orang Tua

Sebagaimana maklum, peran orang tua menempati posisi puncak dalam pembentukan karakter anak. Dalam hal ini, Kartini Kartono menyatakan:

"Salah satu kewajiban dan hak utama dari orang tua yang tidak dapat dipisahkan adalah mendidik anak-anaknya, maka diperlukan adanya beberapa pengetahuan tentang pendidikan, misalnya apakah mendidik itu, apa tujuan dan bagaimana cara mendidik dan sebagainya". ${ }^{23}$

Orang tua semacam ini biasanya menganggap pendidikan agama itu sangat penting artinya bagi anak, sehingga mereka betul-betul melaksanakan dan memperbaiki serta memperhatikan terhadap pembinaan agama anak sebab mereka telah mengalami dan merasakan hasilnya.

2. Motivasi beragama

Motivasi beragama dapat diartikan sebagai usaha yang ada dalam diri manusia, yang mendorongnya untuk berbuat suatu tindak keagamaan dengan tujuan tertentu atau usaha yang menyebabkan seseorang beragama. ${ }^{24}$

3. Lingkungan Sosial

\footnotetext{
22 A. Tafsir, dkk., Cakrawala Pemikiran Pendidikan Islam, (Bandung: Mimbar Pustaka, 2004), 152.

${ }^{23}$ KartiniKortono, Peranan Keluarga Memandu Anak (Jakarta: Rajawali, 1989), 37.

24 Sururin, Ilmu Jiwa Agama (Jakarta: Raja GrafindoPersada, 2004), 70. 
Lingkungan masyarakat merupakan lingkungan kedua bagi anak dan merupakan salah satu lingkungan yang sangat mempengaruhi anak dalam menerima bermacam-macam pengalaman baik yang bersifat negatif dan positif. Hal ini menunjukkan bahwa anak akan memperoleh pengetahuan yang berbeda satu dengan lainnya tergantung tempat tinggal.

\section{Daya Penghambat Pembinaan Agama Anak dalam Keluarga}

1. Kurangnya komunikasi antara orang tua dengan anak

Masalah-masalah yang dihadapi oleh orang tua dan anak karena adanya hambatan komunikasi antara kedua belah pihak. Faktor-faktor yang menjadi penghambat itu, pertama, orang tua biasanya merasa kedudukannya lebih tinggi dari pada kedudukan anaknya yang menginjak usia anak. Kedua, orang tua dan anak tidak mempergunakan bahasa, sehingga menimbulkan salah tafsir atau salah fahaman. Ketiga, orang tua hanya memberikan informasi, akan tetapi ikut serta memecahkan masalah-masalah yang dihadapi oleh anak. Keempat, anak tidak diberi kesempatan untuk mengembangkan kreatifitasnya serta memberikan pandangan-pandangan secara bebas.

Menurut Syaiful Bahri Djamarah, pola komunikasi yang dibangun akan mempengaruhi pola asuh orang tua. Dengan pola komunikasi yang baik diharapkan akan tercipta pola asuh yang baik. kegiatan pengasuhan anak akan berhasil dengan baik jika pola komunikasi yang tercipta dilembari dengan cinta dan kasih sayang dengan memposisikan anak sebagai subjek yang dibina dan dididik bukan sebagai objek semata. ${ }^{25}$

2. Sikap anak dalam beragama

Bagi sebagian anak mempelajari agama sudah dianggap bukan jamannya. Mempelajari agama hanya untuk orang yang usianya sudah tua. Kebanyakan anak percaya kepada Allah dan menjalankan ajaran agama karena terdidik dalam lingkungan beragama, karena orangtuanya, teman-teman dan masyarakat

${ }^{25}$ Syaiful Bahri Djamarah, Pola Komunikasi Orang Tua dan Anak Dalam Keluarga (Jakarta: Rineka Cipta, 2004), 2. 
sekelilingnya yang beribadah, maka mereka ikut percaya dan melaksanakan ibadah dan ajaran agama sekedar mengikuti suasana lingkungan sekitarnya. ${ }^{26}$

Zakiah Daradjat juga menambahkan, kebimbangan anak terhadap ajaran agama tergantung pada dua faktor penting, yaitu kondisi jiwa yang bersangkutan dan keadaan sosial budaya yang melingkupi. Keraguan tersebut diperoleh anak ketika mereka melihat keadaan masyarakat yang dipenuhi dengan penderitaan, kemerosotan moral, kekacauan dan kebingungan. ${ }^{27}$

\section{Pengaruh Keluarga Terhadap Pendidikan Agama Anak}

Keluarga merupakan lingkungan pertama bagi seorang anak, ketika anak dilahirkan maka orang tualah yang menemani, menjaga dan membesarkannya. ${ }^{28}$ Tugas mendidik anak berada dipundak setiap orang tua sebab dari merekalah proses kelahiran terjadi. ${ }^{29}$ Dari aspek ajaran Islam, mendidik anak merupakan kewajiban orang tua untuk mempersiapkan anak-anaknya agar memiliki masa depan gemilang dan tidak ada lagi kekhawatiran terhadap masa depannya kelak. ${ }^{30}$

Dalam melaksanakan pendidikan Agama perlu diperhatikan adanya faktorfaktor pendidikan yang ikut menentukan berhasil atau tidaknya pendidikan agama tersebut.

Menurut Imam Barnadib, lingkungan pendidikan dibagi tiga yakni lingkungan keluarga, lingkungan sekolah dan lingkungan masyarakat. ${ }^{31}$ Lingkungan keluarga adalah merupakan lembaga pendidikan tertua, bersifat informal, yang pertama dan utama dialami oleh anak. Lingkungan keluarga juga disebut lembaga pendidikan yang bersifat kodrat.

Anak sebagai terdidik dalam keluarga memperoleh sikap, nilai dan ketrampilan serta pengetahuan dari pengalaman sehari-hari. ${ }^{32}$ Keluarga juga merupakan tempat pendidikan utama dan pertama, karena di dalam keluarga anak

\footnotetext{
26 Sururin, Ilmu Jiwa Agama,73

${ }^{27}$ Daradjat, Pengajaran Agama Islam,101

28 Enipurwati dkk, Pendidikan Karakter (Surabaya: Kopertais IV Press, 2014), 177.

${ }^{29}$ Moh.Rokib, Ilmu Pendidikan Islam (Yogyakarta: LKiS, 2009), 37.

${ }^{30}$ Rokib, Imu Pendidikan, 40.

31 Sutari Imam Barnadib, Pengantar Ilmu Pendidikan Sistematis, (Yogjakarta: FIP IKIP, 1976), 118

32 A.Muri Yusuf, Pengantar Ilmu Pendidikan (Jakarta: Ghalia 1982), 62. 
pertama-tama menerima pendidikan yang diperoleh dalam keluarga adalah merupakan pendidikan yang penting terhadap perkembangan pribadi anak, sebagai mana dikemukakan oleh Zakiyah Daradjat :

"Orang tua adalah pusat dari kegiatan kehidupan rohani bagi si anak dan sebagai penyebab perkenalannya dengan alam luar, maka setiap reaksi emosi anak dan pemikirannya dikemudian hari, terpengaruh oleh sikapnya terhadapa orang tua dipermulaan hidupnya dahulu" 33

Pendapat di atas menjelaskan bahwa pendidikan dalam keluarga bersifat kodrat, artinya suasana dan struktur keluarga itu memberikan kemungkinan alami untuk terciptanya situasi pendidikan. Situasi tersebut dapat terwujud berkat adanya pergaulan dan hubungan pengaruh mempengaruhi secara timbal balik antara kedua orang tua, bapak, ibu dan anak.

\section{Lingkungan masyarakat}

Lingkungan masyarakat adalah merupakan lingkungan ketiga dalam proses pembentukan kepribadian anak-anak sesuai dengan keberadaannya. Lingkungan massyarakat akan memberikan sumabangan yang sangat berarti dalam diri anak apabila diwujudkan dalam proses dan pola yang tepat.

Tidak semua ilmu pengetahuan, sikap, ketrampilan dapat dikembangkan oleh sekolah ataupun keluarga, karena keterbatasan dana dan kelengkapan tempat tersebut. Kekurangan tersebut akan dapat diisi dan dilengkapi oleh lingkungan masyarakat dalam membina pribadi anak didik atau individu secara utuh dan terpadu.

Pendidikan dalam masyarakat sebagai mana yang dikemukakan oleh Muri Yusuf, bahwa pendidikan dalam masyarakat adalah berfungsi sebagai pelengkap, pengganti, dan tambahan. ${ }^{34}$

Maksudnya sebagai pengganti adalah bahwa pendidikan masyarakat berfungsi sama dengan pendidikan formal di sekolah, dan berfungsi sebagai taambahan karena keterbatasan jam pelajaran, maka diadakan kursus di luar program pendidikan yang ada. Dengan demikian jelaslah bagi kita bahwa lingkungan masyaraakat menetukan

\footnotetext{
33 Zakiyah Daradjat, Pendidikan Islam Dalam Keluarga Dan Sekolah,(Jakarta: CV Ruhama,1995),51.
}

34 Yusuf, Pengantar Ilmu Pendidikan, Ghalia, 62. 
dan memberikan pengaruh terhadap pembentukan pribadi tiap-tiap individu atau anak dengan mengingat ketiga fungsi tersebut.

\section{Gambaran Objek Penelitian}

Lokasi penelitian dilakukan didesa Labruk lor Kecamatan Lumajang Kabupaten Lumajang Jawa Timur. Desa Labruk Lor adalah salah satu desa dari 12 desa di Wilayah Kecamatan Lumajang. Secara geografis Desa Labruk Lor Kecamatan Lumajang dengan batas-batas: pertama, sebelah utara berbatasan dengan Kelurahan Citrodiwangsan Kecamata Luamajang. Kedua, sebelah selatan berbatasan dengan Desa Labruk Kidul Kecamatan Lumajang, Ketiga, sebelah barat berbatasan dengan Desa Petahunan Kecamatan Lumajang. Keempat, sebelah timur berbatasan dengan Desa Grati Kecamatan Lumajang. ${ }^{35}$

Desa Labruk Lor Kecamatan Lumajang terbagi menjadi 4 (empat) Dusun, 5 RW dan 17 RT Yaitu: 1) Dusun I dengan nama lain Dusun Krajan, terdiri dari 1 RW yaitu RW 01, dan dibantu oleh 04 RT, 2) Dusun II dengan nama lain Dusun Laban, terdiri dari 1 RW yaitu RW 02, dan dibantu oleh 03 RT, 3)Dusun III dengan nama lain Dusun Panjang Sari, terdiri dari 1 RW yaitu RW 03 dengan dibantu oleh 03 RT, 4) Dusun IV dengan nama lain Dusun Jurang Mangu, terdiri dari 2 RW yaitu RW 4,RW 5 dengan dibantu oleh 4 RT. ${ }^{36}$

Desa Labruk Lor Kecamatan Lumajang dengan jumlah penduduk sebesar 3.305 jiwa yang terdiri dari perincianya sebagai berikut, jumlah penduduk laki-laki: 1.726 jiwa, jumlah penduduk perempuan: 1.647 jiwa, jumlah kepala keluarga: 1.045 KK. ${ }^{37}$ Tingkat pendidikan masyarakat di Desa Labruk Lor antara lain lulusan SD sederajat, SLTP sederajat, SLTA sederajat, Akademi sederajat, dan Universitas. ${ }^{38}$

Berikut tabel data tingkat pendidikan masyarakat Desa Labruk Lor Lumajang.

\begin{tabular}{|l|c|}
\hline \multicolumn{1}{|c|}{ TINGKAT PENDIDIKAN } & JUMLAH \\
\hline Tamatan SD sederajat & 164 \\
\hline Jumlah tamat SMP sederajat & 415 \\
\hline Jumlah tamat SMA sederajat & 217 \\
\hline
\end{tabular}

\footnotetext{
35 Sumber dari profil desa Labruk Lor tahun 2016. Diakses pada 18 April 2018

${ }^{36}$ Sumber dari profil Desa Labruk Lor tahun 2016. Diakses pada 18 April 2018

${ }^{37}$ Sumber dari profil Desa Labruk Lor tahun 2016. Diakses pada 18 April 2018

38 Sumber dari profil Desa Labruk Lor tahun 2016. Diakses pada 18 April 2018 


\begin{tabular}{|l|c|}
\hline Akademi/sederajat & 25 \\
\hline Universitas/Perguruan Tinggi & 48 \\
\hline
\end{tabular}

Sumber: Profil Desa Labruk Lor tahun 2016

Berdasarkan data pada tabel di atas dapat diketahui bahwa tingkat pendidikan masyarakat desa Labruk Lor rata-rata adalah lulusan Sekolah Menengah Pertama dengan jumlah 415 jiwa, namun masih banyak masyarakat yang tamatan sekolah dasar dengan jumlah 164.

Tingkat pendapatan rata-rata penduduk desa Labruk Lor $<$ Rp. 500.000,-/ lebih per bulan. ${ }^{39}$ Secara umum mata pencaharian warga masyarakat desa Labruk Lor dapat teridentifikasi ke dalam beberapa sektor yaitu : petani, buruh tani, pedagang, pengerajin, pengusaha, tukang becak, tukang ojek, buruh pabrik dan lain-lain. ${ }^{40}$

Jumlah Penduduk dari masing-masing mata pencarihan di atas dapat dilihat pada table berikut:

\begin{tabular}{|c|c|c|c|}
\hline NO & JENIS PEKERJAAN & LAKI - LAKI & PEREMPUAN \\
\hline 1. & Petani & 118 Orang & - Orang \\
\hline 2. & Buruh Tani & 98 Orang & 102 Orang \\
\hline 3. & TKI / TKW & 4 Orang & 7 Orang \\
\hline 4. & $\begin{array}{l}\text { Pengrajin } \\
\text { Industri Rumah Tangga }\end{array}$ & 5 Orang & 3 Orang \\
\hline 5. & Pedagang Keliling & 21 Orang & 13 Orang \\
\hline 6. & Peternak & 26 Orang & - Orang \\
\hline 7. & Buruh Pabrik & 125 Orang & 123 Orang \\
\hline 8. & Montir & 5 Orang & - Orang \\
\hline 9. & Bidan Swasta & - Orang & 1 Orang \\
\hline 10. & Perawat Swasta & - Orang & 5 Orang \\
\hline 11. & Pembantu Rumah Tangga & - Orang & 10 Orang \\
\hline 12. & TNI & 4 Orang & - Orang \\
\hline 13. & Polri & 6 Orang & 1 Orang \\
\hline 14. & $\begin{array}{l}\text { Pengusaha Kecil } \\
\text { Menengah }\end{array}$ & 85 Orang & 103 Orang \\
\hline 15. & Dosen Swasta & 1 Orang & Orang \\
\hline 16. & Pengusaha Besar & 2 Orang & - Orang \\
\hline 17. & Seniman/Artis & 3 Orang & - Orang \\
\hline 18. & $\begin{array}{l}\text { Karyawan Perusahaan } \\
\text { Swasta }\end{array}$ & 10 Orang & 29 Orang \\
\hline
\end{tabular}

${ }^{39}$ Nuki Rafsanjani, Wawancara, Labruk Lor, 10 April 2018

${ }^{40}$ Sumber dari profil Desa Labruk Lor tahun 2016. Diakses pada tanggal 18 April 2018 


\begin{tabular}{|l|l|l|c|}
\hline 19. & $\begin{array}{l}\text { Karyawan Perusahaan } \\
\text { Pemerintahan }\end{array}$ & 15 Orang & 21 Orang \\
\hline 20. & Makelar/Broker/Mediator & 5 Orang & - Orang \\
\hline 21. & Sopir & 21 Orang & - Orang \\
\hline 22. & Tukang Becak & 24 Orang & - Orang \\
\hline 23. & Tukang Cukur & 3 Orang & - Orang \\
\hline 24. & Tukang Batu/Kayu & 28 Orang & - Orang \\
\hline
\end{tabular}

Sumber: Profil Desa Labruk Lor tahun 2016

Mata Pencarihan sebagian besar masyarakat desa Labruk Lor adalah sebagai buruh pabrik dengan jumlah 248 jiwa. Masyarakat cenderung bekerja sebagai buruh pabrik karena memang banyak pabrik-pabrik diberbagai bidang di sekitar desa Labruk Lor. Selain itu juga banyak masyarakat yang bekerja sebagai buruh tani dengan jumlah 200 jiwa. Hal ini didukung karena banyaknya lahan persawahan yang luas di desa Labruk Lor.

Dengan adanya perubahan- perubahan dinamika kehidupan masyarakat desa Labruk Lor tetap hidup rukun, tentram dan damai dibuktikan dengan tidak pernah terjadi kerusuhan antar warga. Rasa persaudaraan dan kekeluargaan antar warga masih terjalin dengan baik smapai sekarang ini dan masih ada dan suasana budaya masyarakat jawa masih terasa di desa Labruk lor, dalam kegiatan keagamaan misalnya masih adanya budaya selametan, tahlilan, pengajian dan lainnya yang semua merefleksikan sisi-sisi akulturasi budaya Islam di Jawa. Berikut kegiatan sosial budaya yang masih berjalan di desa Labruk Lor.

1. Selamatan dalam memperingati acara-acara seperti, empat bulanan, tujuh bulanan bagi wanita yang sedang hamil, selamatan bagi anak yang baru lahir, selamatan aqiqoh anak, dan selamatan pernikahan (mantenan) dan lainnya.

2. Perkumpulan atau arisan baik itu dari warga laki-laki atau pun perempuan yang dilaksanakan bersamaaan dengan pengajian (bagi warga laki-laki) yang dilaksanakan dengan bergilir dari rumah ke rumah warga yang lainnya. Hal ini bertujuan untuk menjalin sliaturrahmi antar warga.

3. Tahlilan yaitu ketika ada salah satu anggota keluarga warga desa labruk lor yang meninggal acara dilaksanakan selama 7 hari, 40 hari, 100 hari dan seterusnya. yang dilakukan di rumah keluarga yang meninggal. 
4. Pengajian baik pengajian antara ibu-ibu maupun bapak-bapak, yang dimana pengajian ibu-ibu biasanya dilakukan di mushola-mushola setempat pada hari jum'at dan hari rabu malam dan untuk bapak-bapak dilaksnakan pada hari kamis dan sabtu malam minggu di rumah- rumah warga secara bergantian.

Kegiatan sosial masyarakat desa Labruk lor lebih bercondong pada kegiatankegiatan keagamaan yakni agama Islam hal ini dikarenakan mayoritas keyakinan masyarakat desa Labruk Lor adalah Agama Islam. Berikut tabel jumlah masyarakat berdasarkan keyakinan yang dianutnya.

\begin{tabular}{|l|r|r|}
\hline JENIS AGAMA & LAKI - LAKI & PEREMPUAN \\
\hline Islam & 1.617 Orang & 1.644 Orang \\
\hline Kristen & 11 Orang & Orang \\
\hline Katholik & - Orang & - Orang \\
\hline Hindu & - Orang & - Orang \\
\hline Budha & - Orang & - Orang \\
\hline Konghuchu & - Orang & - Orang \\
\hline $\begin{array}{l}\text { Kepercayaan Tuhan Yang Maha } \\
\text { Esa }\end{array}$ & - Orang & - Orang \\
\hline Aliran Kepercayaan Lain & - Orang & - Orang \\
\hline
\end{tabular}

Sumber: Profil desa Labruk Lor tahun 2016

\section{Pola Pembinaan Agama Dalam Kelurga Buruh Pabrik Di Desa Labruk Lor Lumajang}

Pola Pembinaan agama adalah Usaha atau cara untuk memberikan gambaran kepada anak atas kegiatan yang sudah ada dan dilakukan agar menuju yang lebih baik melalui bimbingan dan memberikan pengetahuan dan kecakapan yang baru. Keberhasilan keluarga dalam menanamkan nilai-nilai keagamaan pada anak sangat tergantung pada jenis pola asuh / pembinaan yang diterapakan oleh orang tua. Bermacam-macam pengasuhan dilakukan orangtua dalam mendidik anak. Yaitu pola asuh permisif (acuh tak acuh kepada anak), pola asuh otoriter dan pola asuh demokratis. Dari berbagai macam pola pembinaan yang ada, pola yang tepat dalam mendidik agama anak adalah pola pembinaan / asuh yang demokratis yang dimana Kedudukan antara orang tua dan anak sejajar. Anak diberi kebebasan yang bertanggung jawab, artinya apa yang dilakukan oleh anak tetap harus dibawah 
pengawasan orang tua dan dapat dipertanggung jawabkan secara moral. Orang tua dan anak tidak dapat berbuat semena-mena. Anak diberi kepercayaan dan dilatih untuk mempertanggung jawabkan segala tindakannya.

Dari uraian di atas, nampaknya karya Bakir Yusuf Barmawi relevan dengan penelitian ini. Dalam hal ini, ia mengatakan:

"Anak sebagai amanah dari Allah, membentuk 3 dimensi hubungan, dengan orang tua sebagai sentralnya. Pertama, hubungan kedua orang tuanya dengan Allah yang dilatarbelakangi adanya anak. Kedua, hubungan anak (yang masih memerlukan banyak bimbingan) dengan Allah melalui orang tuanya. Ketiga, hubungan anak dengan kedua orang tuanya di bawah bimbingan dan tuntunan dari Allah." ${ }^{41}$

Dalam syari'at Islam sudah diajarkan bahwa mendidik dan membimbing anak merupakan suatu kewajiban bagi seorang muslim, karena anak merupakan amanat yang harus dipertanggung jawabkan oleh orangtua. Islam sebagai agama rahmatan lil 'alamin menawarkan langkah-langkah mendidik anak yang menjadi solusi dalam keluarga sesuai dengan petunjuk Al-Qur'an dan Al-Hadits. ${ }^{42}$

\section{Daya Dukung dan Hambat Pembinaan Agama dalam Keluarga Buruh Pabrik di Desa Labruk Lor Lumajang}

Dari hasil observasi dan wawancara yang dilakukan oleh penulis menunjukkan, bahwa daya dukung dalam pemilihan pola pembinaan dalam keluarga buruh pabrik di desa Labruk Lor yakni dikarenakan faktor ekonomi dalam keluarga, faktor lingkungan sekitar keluarga, faktor bawaan dari keluarga terdahulu dan faktor budaya di lingkungan sekitar. Hal ini juga sesuai dengan pendapat Horlock yang menjelaskan bahwa orang tua yang berasal dari tingkat sosial ekonomi menengah lebih bersikap hangat dibandingkan orang tua yang berasal dari sosial ekonomi yang rendah. Latar belakang pendidikan orang tua yang lebih tinggi dalam praktek asuhannya terlihat lebih sering membaca artikel ataupun mengikuti perkembangan pengetahuan mengenai perkembangan anak. Dalam mengasuh anaknya mereka menjadi lebih siap karena memiliki pemahaman yang lebih luas, sedangkan orang tua

${ }^{41}$ Bakir Yusuf Barmawi, Pembinaan Kehidupan Beragama Islam Pada Anak (Semarang: Dina Utama, 1993), 5

42 Padjrin, "Pola Asuh Anak Anak dalam Perspektif Pendidikan Islam”, Intelektualita, Volume 5, Nomor 1, 2016.

244 | Tarbiyatuna: Jurnal Pendidikan Islam; Volume 11, Nomor 2, Agustus 2018 p-ISSN: 2085-6539, e-ISSN: 2242-4579 
yang memiliki latar belakang pendidikan terbatas, memiliki pengetahuan dan pengertian yang terbatas mengenai kebutuhan dan perkembangan anak sehingga kurang menunjukan pengertian dan cenderung akan memperlakukan anaknya denga ketat dan otoriter.

Kepribadian orang tua dapat mempengaruhi penggunaan pola asuh. Orang tua yang konservatif cenderung akan memperlakukan anaknya dengan ketat dan otoriter. Orang tua yang memiliki anak hanya 2-3 orang (keluarga kecil) cenderung lebih intensif pengasuhannya, di mana interaksi antara orang tua dan anak lebih menekankan pada perkembangan pribadi dan kerja sama antar anggota keluarga lebih dperhatikan. Sedangakan orang tua yang memiliki anak berjumlah lebih dari lima orang (keluarga besar) sangat kurang memperoleh kesempatan untuk mengadakan kontrol secara intensif antara orang tua dan anak, karena orang tua secara otomatis berkurang perhatiannya pada setiap anak. ${ }^{43}$

\section{Dampak bagi Anak dari Pembinaan Agama dalam Kelurga Buruh Pabrik di Desa Labruk Lor Lumajang}

Dari bermacam-macam pola yang diterapkan oleh setiap keluarga memiliki dampak yang berbeda-beda pula pada anak mereka berikut dampak yang terdapat dalam keluarga buruh pabrik :

\begin{tabular}{|c|c|c|c|}
\hline NO & $\begin{array}{ll}\text { Pola } & \text { Yang } \\
\text { Digunakan } & \end{array}$ & Dampak Positiv & Dampak Negatif \\
\hline 1. & Permisif & $\begin{array}{l}\text { Pemberian kebebasan } \\
\text { kepada anak dan jika } \\
\text { digunakan dengan baik } \\
\text { anak akan mampu } \\
\text { menjadi pribadi yang } \\
\text { mandiri, kratif dan } \\
\text { gembira }\end{array}$ & $\begin{array}{l}\text { Kecenderugan anak yang } \\
\text { kurang perhatian } \\
\text { membuat anak mencari } \\
\text { perhatian dengan cara } \\
\text { lain yakni nakal, tidak } \\
\text { memiliki rasa takut, tidak } \\
\text { memiliki rasa tanggung } \\
\text { jawab }\end{array}$ \\
\hline 2. & Otoriter & $\begin{array}{l}\text { Dengan peraturan- } \\
\text { perauran yang dibuwat } \\
\text { dalam keluarga membuat } \\
\text { anak lebih disiplin, } \\
\text { bertanggung jawab dan }\end{array}$ & $\begin{array}{l}\text { Anak menjadi lebih } \\
\text { pendiam, senang } \\
\text { menyendiri, dan } \\
\text { memiliki tekanan batin. }\end{array}$ \\
\hline
\end{tabular}

${ }^{43}$ Hurlock, Elizabeth B, Psikologi Perkembangan Suatu Pendekatan Sepanjang Masa. Edisi kelima (Jakarta: Erlangga, 1997) 


\begin{tabular}{|l|l|l|l|}
\hline 3. & taat kepada orang tua & \\
\hline & Demokratis & $\begin{array}{l}\text { anak anak lebih berani } \\
\text { dan terbuka kepada } \\
\text { orang tua, bertanggung } \\
\text { jawab pada waktuu, } \\
\text { sopan terhadap orang } \\
\text { tua dan anak mampu } \\
\text { menyadari kesahan yang } \\
\text { diperbuatnya }\end{array}$ \\
\hline
\end{tabular}

\section{Kesimpulan}

Pola pembinaan permisif adalah jenis pola mengasuh anak yang acuh tak acuh terhadap anak, jadi apapun yang mau dilakukan anak diperbolehkan dan hal ini memberikan dampak positif dan negatif. Dampak positif Pemberian kebebasan kepada anak dan jika digunakan dengan baik anak akan mampu menjadi pribadi yang mandiri, kreatif dan gembira dan dampak negatif kecenderugan anak yang kurang perhatian membuat anak mencari perhatian dengan cara lain yakni nakal, tidak memiliki rasa takut, tidak memiliki rasa tanggung jawab.

Pola Pembinaan otoriter adalah pola pengasuhan anak yang bersifat memaksa, keras dan kaku dimana orang tua akan membuat berbagai macam aturan yang harus di patuhi oleh anak tanpa mau tau perasaan sang anak Memberikan dampak pada anak yakni Dampak positive dengan peraturan- perauran yang dibuwat dalam keluarga membuat anak lebih disiplin, bertanggung jawab dan taat kepada orang tua. Dan dampak negatif Anak menjadi lebih pendiam, senang menyendiri, dan memiliki tekanan batin.

Pola pembinaan demokratis adalah pola asuh yang dimana memberikan kebebasan anak untuk berkreasi dan mengeksporasi berbagai hal sesuai dengan kemampuan anak dengan batasan dan pengawasan yang baik dari orang tua. Memberikan dampak pada anak anak anak lebih berani dan terbuka kepada orang tua, bertanggung jawab pada waktuu, sopan terhadap orang tua dan anak mampu menyadari kesahan yang diperbuatnya.

\section{Referensi}


Ahmadi, Abu, dan Munawar Sholeh. 2005. Psikologi Perkembangan. Jakarta: PT. Rineka Cipta.

Ahmadi, Abu. 2007. Sosiologi Pendidikan, Jakarta: Rineka Cipta.

Barmawi, Bakir Yusuf. 1993. Pembinaan Kehidupan Beragama Islam Pada Anak, Semarang: Dina Utama.

Barnadib, Sutari Imam. 1976. Pengantar Ilmu Pendidikan Sistematis, Yogyakarta: FIP IKIP.

D. Soemarno, 1998. Pedoman Pelaksanaan Disiplin Nasional dan Tata Tertib Sekolab 1998, Jakarta: CV. Mini Jaya Abadi.

Daradjat, Zakiyah. 1995. Pendidikan Islam Dalam Keluarga Dan Sekolah, Jakarta: CV Ruhama.

Daradjat, Zakiyah. 1995. Pengajaran Agama Islam, Jakarta: Bumi Aksara.

Djamarah, Syaiful Bahri. 2004. Pola Komunikasi Orang Tua dan Anak Dalam Keluarga, Jakarta: Rineka Cipta.

Gunarsa, Singgih. 2000. Pengantar Psikologi Edisi Kesebelas. Batam :Interaksara Gunarsa. Psikologi Perkembangan. Jakarta : PT BPK Gunung Mulia.

Gunarsa, Singgih. 2006. Dasar dan Teori Perkembangan Anak, Jakarta: BPK Gunung Mulia.

Hasan, Alwi, 2005. Kamus Umum Bahasa Indonesia Jakarta: Balai Pustaka.

Hurlock, Elisabeth. 2006. Psikologi Perkembangan Edisi Kelima, Jakarta: Erlangga.

Hurlock, Elizabeth B. 1997. Psikologi Perkembangan Suatu Pendekatan Sepanjang Masa. Edisi kelima, Jakarta: Erlangga.

Kortono, Kartini. 1989. Peranan Keluarga Memandu Anak, Jakarta: Rajawali.

Kountur, Ronny. 2003. Metode Penelitian Untuk Penulisan Skripsi dan Tesis, cet. ke-1 Jakarta: PPM.

Kurniawan, Syamsul. 2016. Pendidikan Karakter.Yogyakarta: Ar-Ruzz Media.

Moleong, Lexy J. 2004. Metodologi Penelitian Kualitatif, Bandung: PT. Anak Rosda karya.

Mussen, P. H. 1989. Pengembangan dan Kepribadian Anak, Jakarta: Arcan.

Nata, Abuddin. 2002. Tafsir Ayat - ayat Pendidikan Tafsir al-Ayat al-Tarbany, Jakarta: PT. Raja Grafindo Persada.

Padjrin, 2016. Pola Asub Anak Anak dalam Perspektif Pendidikan Islam, Intelektualita Volume 5, Nomor 1.

Proboningrum, C. S. 1993. Psikologi Perkembangan. Yogyakarta: Gadjah Mada University Press.

Purwati, Eni dkk. 2014. Pendidikan Karakter, Surabaya: Kopertais IV Press. 
Rokib, Moh. 2009. Ilmu Pendidikan Islam, Yogyakarta: LKiS Yogyakarta.

Hidayat, S. 1987.Pembinaan Generasi Muda, Surabaya: Study Group.

Semiawan, Conny dkk. 2008. Pengenalan dan Pengembangan Bakat Sejak Dini. Bandung: PT. Remaja Rosda Karya.

Sumber dari profil desa Labruk Lor tahun 2016. Diakses pada 18 April 2018

Surakhmad, Winarno. 1990. Pengantar Penelitian Ilmiah 9 Dasar Metode Teknik, Bandung: Tarsito.

Sururin. 2004. Ilmu Jiwa Agaman, Jakarta: Raja Grafindo Persada.

Surya, Mohamd. 2003. Bina Keluarga, Semarang: CV. Aneka Ilmu.

Tafsir, A. dkk. 2004. Cakrawala Pemikiran Pendidikan Islam, Bandung: Mimbar Pustaka. Yusuf , A. Muri. 1982. Pengantar Ilmu Pendidikan, Jakarta: Ghalia. 